\title{
Türkiye'de Tartışmalı ve Sosyobilimsel Konular Üzerine Yazılan Lisansüstü Tezlerin Eğitim Bilimleri Perspektifinden İncelenmesi ${ }^{*}$
}

\author{
Şefika TATAR, Oktay Cem ADIGÜZEL ${ }^{* *}$
}

Türkiye'de Tartışmalı ve Sosyobilimsel Konular Üzerine Yazılan Lisansüstü Tezlerin Eğitim bilimleri Perspektifinden İncelenmesi

Özet
Bu çalışma kapsamında, 2007-2016 yılları arasında
Türkiye'de tartışmalı ve sosyobilimsel konular üzerine
gerçekleştirilen tezlerin yüksek lisans ve doktora
düzeylerine, yıllara ve anabilim/bilim dallarına, konu
alanlarına ve araştırma modellerine göre dağılımlarının
incelenmesi amaçlanmıştır. Betimsel tarama modelin-
de desenlenen bu çalışmada tezler, araştırmacı tara-
fından hazırlanan bir betimsel analiz formu doğrultu-
sunda incelenmiştir. Yapılan analizler sonucunda
tartışmalı ve sosyobilimsel konuların ağırlıklı olarak
ilköğretim ve yükseköğretim düzeyindeki tezlerde
araştırma konusu yapıldığı tespit edilmiştir. Tartışmalı
ve sosyobilimsel konular üzerine yapılan çalışmaların
konu alanları incelendiğinde çalışmaların yoğunluklu
olarak fen ve biyoetik konularında gerçekleştirildiği,
bunların dışında kalan konularda çok sınırlı sayıda
kaldığı gözlenmiştir. Sosyobilimsel konuların bilişsel
beceriler üzerindeki etkisi en çok araştırılan konu
olurken; bu konularla ilgili duyuşsal beceriler en çok
araştııın ikinci konu olmuştur.

Anahtar Kelimeler: Tartışmalı Konular, Sosyobilimsel Konular, Biyoetik, Lisansüstü Tezlerde Tartışmalı Ve Sosyobilimsel Konular.
An Investigation of Dissertations on Controversial and Socioscientific Issues in Turkey From The Perspective of Educational Sciences

Abstract

This study aims to investigate the dissertations on controversial and socioscientific issues in Turkey between the years 2007 and 2016 in terms of master and doctorate levels, years and departments/disciplines, topics, target groups and research designs of dissertations on controversial and socioscientific issues with regard to the descriptive analysis form prepared by the researcher. The study was designed as a descriptive survey model research. The study revealed that controversial and socioscientific issues mostly focused on elementary and higher education. In addition, most of the dissertations on controversial and socioscientific issues are associated with science and bioethics, the other issues are limited in quantity. While the effect of socioscientific issues on cognitive abilities is mostly searched in dissertations, second mostly searched subject is the effect of socioscientific issues on affective abilities.

\section{Giriş}

Bireylere kazandırılması gereken bilgi, beceri ve tutumlar; küresel ekonomi, kıtlık, salgın hastalıklar ve ırkçılık gibi 21. yüzyılda tüm dünyayı ilgilendiren problemlerden etkilenmektedir (Curriculum Standing Committee of National Education Professional Associa-

\footnotetext{
* Bu çalışma 5. Uluslararası Eğitim Programları ve Öğretim Kongresi'nde sözlü bildiri olarak sunulmuştur.

** Şefika TATAR, Öğretmen, Batuhan Ortaokulu, sefika_tatar@hotmail.com, ORCID ID orcid.org/0000-0001-86997451, Oktay Cem ADIGÜZEL, Prof. Dr. Anadolu Üniversitesi, Eğitim Fakültesi, ocadiguzel@anadolu.edu.tr, ORCID ID https://orcid.org/0000-0002-7985-4871
} 
tions [CSCNEPA], 2007). Küreselleşmenin hız kazandığı bu yüzyılda, geleceğin tüm uluslara ne tür tehditler getireceği yeterince bilinmemektedir. Dolayısıyla, olası problemlerle başa çıkabilecek yetilere sahip olmak, küresel sürdürülebilirliğin gereklerindendir. Günümüzde çocuklar, küresel farklılıklar, riskler ve bundan doğabilecek çatışmalarla nasıl başa çıkılacağını öğrenmek zorundadırlar (Claire ve Holden, 2007). Bu sebeple eğitim programlarının 21. yüzyıl gereklilikleri çerçevesinde öğrencileri hızlı değişime uyum sağlayacak becerilerle donatacak şekilde yapılandırılması kaçınılmazdır (Fındıkçı, 2004).

Ülkeler, 21. yüzyılın gerektirdiği insan tipini yetiştirmek için eğitim programlarında tartışmalı konulara yer vermeye başlamıştır. Tartışmalı konular, zıt bakış açıları barındıran mantıklı anlaşmazlıklar (Levinson, 2008) ya da değer yargıları içeren ve bu sebeple kanıta dayalı olarak çözümlenemeyen konulardır (Wellington, 1986). Eğer bir konu hakkında mantığa uygun ama birbiriyle çelişen fikirler ileri sürülebiliyorsa o mesele tartışmalıdır (Dearden, 1981). Bu sebeple hemen her konunun öğretiminde tartışmalı konular ortaya çıkabilir. Ülkelerin eğitim programlarında tartışmalı konulara yer verilmekle birlikte bu konular küresel düzeyde olabileceği gibi ulusal sınırlarda da kalabilmektedir. Çünkü bir konunun tartışmalı olup olmaması ideolojik ve bağlamsaldır. Bir taraftan içinde yaşanılan toplumda hâkim olan ideoloji diğer taraftan o toplumun değer yargıları ve inançları neyin tartışmalı olduğunu belirler. Örneğin Türkiye'de Ermeni Meselesi ve Evrim tartışmalı konular iken İngiltere'de uyuşturucu bağımlılığı ve göç konuları tartışmalı olabilir.

Tarihsel süreç incelendiğinde Amerika Birleşik Devletleri'nde tartışmalı konuların sosyal bilgileri oluşturan disiplinlerin altında ele alındığı görülmektedir (Hoge, 1988). 1916 tarihli Amerikan Sosyal Bilgiler Milli Eğitim Komisyonu Komite Raporu'nda, sosyal problemlerin öğretilmesi, vatandaşlık eğitiminde ön plana çıkarılmış ve 12. sınıflara "Demokrasinin Problemleri" dersi adlı bir ders koyulmuştur. 1930'lar ve 1940'ların başında Harold Rugg'ın yazdığı sosyal bilgiler ders kitabı serileri ve 1960'larda tasarlanan Kamusal Sorunlar Modeli, çocuklara sosyal problemlerin öğretilmesi düşüncesini bir adım ileri götürmüştür (Bohan ve Feinberg, 2008; Evans, 2010, Akt. Kruger, 2012). Amerika Birleşik Devletleri'nde Sosyal Bilgiler Ulusal Konseyi'nin (National Council for Social Studies [NCSS], 2016) raporunda, tartışmalı konuların öğretilmesi sonucu sosyal sorunları öğrenme, eleştirel düşünme ve uzlaşmaya gönüllü olma gibi öğrencilerde gelişmesi beklenen tutum ve beceriler ortaya konmuştur. Sosyal bilgiler dersi Türkiye'de 1968 yılından itibaren bu isimle programlarda yerini almıştır. Ancak, bu dersin felsefesi, amaçları, içeriği ve eğitim durumları 2004 yılına gelinceye kadar pek fazla değişiklik göstermemiştir. Millî Eğitim Bakanlığı'nın (MEB) 2004 yılında yapılandırmacılık felsefesi doğrultusunda gerçekleştirdiği program güncelleme çalışması kapsamında yeni sosyal bilgiler programı 2005-2006 eğitimöğretim yılından itibaren uygulamaya konulmuştur (Çatak, 2015). 2005 yılında uygulanmaya başlanan 4-7. sınıf sosyal bilgiler programında, sadece iki yerde öğretmenin tartışmalı konuları nasıl ele alması gerektiğine değinilmektedir (MEB, 2005). 2017 yılında ger- 
çekleştirilen program güncelleme sonrasında da yine sosyal bilgiler dersi öğretim programında bu konuların sınıfa nasıl taşınabileceğine yer verilmiştir (MEB, 2017).

Sosyal bilgiler ve vatandaşlık eğitimindeki tartışmalı konuların yanı sıra fen bilimini sosyal, kültürel ve politik bir bağlamda ele almayı savunan ve fenle ilgili etik ikilemlere odaklanan sosyobilimsel konular adında bir fen eğitimi yaklaşımı da bulunmaktadır. Sosyobilimsel konular, fenle ilgili sosyal ikilemler barındıran, fen biliminin süreç ve ürünlerinde sosyal olarak zıt düşünceler yaratan tartışmalı konulardır. Son zamanlarda tartışılan sosyobilimsel konular; biyoteknolojik gelişmeler, küresel ısınma, tarım alanlarının yanlış kullanılması gibi çevresel mücadeleleri içermektedir (Sadler ve Zeidler, 2005). Sosyobilimsel konuların içerikleri öğrencilerin günlük yaşamlarında karşı karşıya kalabilecekleri durumlardan kaynaklandığından dolayı öğrencilere bu konuların öğretilmesi fen eğitiminin önemli amaçlarından birisi haline gelmiştir. Bu sebeple sosyobilimsel konular birçok ülkenin fen eğitim programında yerini almıştır. Türkiye'de fen eğitimine ilişkin değişimler 1992 yılında Fen-Teknoloji-Toplum (FTT) yaklaşımı adı altında başlamış, 2000 yılında ilköğretim fen eğitimi programında bu yaklaşımla ilgili kazanımlara ünitelerde yer verilmiştir. 2006 yılında Fen-Teknoloji-Toplum-Çevre (FTTÇ) yaklaşımının açıkça adının geçtiği ilk program uygulanmıştır (Yetişir ve Kaptan, 2008). İlköğretim fen eğitim programları 2013 yılında güncellenmiş ve sosyobilimsel konular bir başlık olarak ilk kez programa dâhil edilmiştir (MEB, 2013). 2017 yılında yapılan program güncellemesinde fen eğitimi bu kez FenTeknoloji-Mühendislik-Matematik (FeTeMM) yaklaşımı üzerine kurulmuştur. 2017 tarihli bu programda da sosyobilimsel konularla ilgili maddeye genişletilerek yer verilmiştir (MEB, 2017). 2017 yılında güncellenen 8. sınıf öğretim programında, daha önce programdan çıkarılan; kalıtım, mutasyon, modifikasyon, adaptasyon ve seçilim konuları tekrar eklenmiş; evrim konusuna ise 2017 programında yine yer verilmemiştir. Bu doğrultuda fen bilimleri öğretim programına sürekli olarak eklenen ya da programdan çıkarılan konuların tartışmalı konular olduğunu söylemek mümkündür.

İlgili alan yazın incelendiğinde tartışmalı konulara hem sosyal bilimler (Healey, 2012; Neal, 2013) hem de fen bilimleriyle (Healey, 2012; Khishfe, 2012; Levinson, 2006) ilgili derslerde yer verildiği görülmektedir. Tarihsel olarak incelendiğinde tartışmalı konuların, daha çok etkili vatandaşlar yetiştirmekle ilişkilendirildiği ve bu sebeple bu konulara ilişkin resmi eğitim politikalarının daha çok sosyal bilgiler ve vatandaşlık eğitimi kapsamında ele alındığı görülmüştür (NCSS, 2016). Bu doğrultuda, Türkiye'de gerçekleştirilen lisansüstü çalışmaların tartışmalı konuların hangi disiplin alanlarına konu olduğu ve hangi boyutlarına odaklandığı ile ilgili bir çalışmaya ihtiyaç olduğu düşünülmektedir.

\subsection{Araştırmanın Amacı}

Bu çalışma kapsamında, 2007-2016 yılları arasında tartışmalı ve sosyobilimsel konular üzerine gerçekleştirilmiş lisansüstü tez çalışmalarının incelenerek, bu konuların ağılıklı olarak hangi anabilim/bilim dalları tarafından araştırma konusu yapıldığının saptanması 
Şefika TATAR | Oktay Cem ADIGÜZEL

ve bu anabilim/bilim dalları içerisinde eğitim bilimleri alanında gerçekleştirilen araştırmaların durumunun betimlenmesi amaçlanmıştır. Çalışmada ayrıca eğitim bilimleri alanına odaklanılarak, tartışmalı ve sosyobilimsel konular ile ilgili gerçekleştirilen lisansüstü tez çalışmalarının eğitim bilimleri alanındaki yeri üzerine bir incelemenin yapılması hedeflenmiştir. Araştırmanın genel amacı doğrultusunda aşağıdaki sorulara yanıt aranmıştır:

1-Türkiye'de tartışmalı ve sosyobilimsel konular üzerine gerçekleştirilen lisansüstü tezlerin yıllara, yüksek lisans ve doktora düzeyleri ile anabilim/bilim dallarına göre dağılımları nasıldır?

2-Türkiye'de tartışmalı ve sosyobilimsel konular üzerine gerçekleştirilen lisansüstü tezlerin konu alanlarına ve hedef kitlelerine göre dağılımları nasıldır?

3-Türkiye'de tartışmalı ve sosyobilimsel konular üzerine gerçekleştirilen lisansüstü tezlerin araştırma modellerine göre dağılımı nasıldır?

\subsection{Araştırmanın Önemi}

Tartışmalı ve sosyobilimsel konuların Türk eğitim tarihindeki ve eğitim programlarındaki yeri incelendiğinde, bu konuların diğer ülkelere kıyasla Türkiye'de çok yakın bir geçmişte ele alınmaya başlandığı görülmektedir. Eğitim alanında tartışmalı ve sosyobilimsel konular üzerine yapılan çalışmaların niteliği ve niceliğinin bu konuların örgün eğitimde ve programlarda daha etkili bir şekilde ele alınmasına katkı sağlayacağı düşünüldüğünden; bu konular üzerine gerçekleştirilen lisansüstü tez çalışmalarının incelenmesinin ve Türkiye'de bu konulara ilişkin yaklaşımın ortaya çıkarılmasının faydalı olacağı düşünülmektedir.

\section{Yöntem}

\subsection{Araştırmanın Modeli}

Türkiye' de eğitim alanında tartışmalı ve sosyobilimsel konular üzerine yazılmış olan lisansüstü tezlerin incelenmesini amaçlayan bu çalışma, betimsel tarama modelinde desenlenmiştir.

\subsection{Verilerin Toplanması}

Araştırma 2016-2017 eğitim-öğretim yılında gerçekleştirilmiştir. Araştırma kapsamında 2007-2016 yılları arasında Türkiye'de tartışmalı ve sosyobilimsel konular üzerine eğitim bilimleri ve sosyal bilimler enstitülerinde gerçekleştirilen lisansüstü tezlerin, araştırma soruları doğrultusunda incelemesi yapılmıştır. Araştırma kapsamında erişime izin verilen tezlere, Yükseköğretim Kurulu Ulusal Tez Merkezinden ulaşılmıştır. Sınırlı erişim izni bulunan tezler incelenirken tez özetlerinden yararlanılmıştır. Araştırma kapsamında tartışmalı konularla ilgili 2 kısıtlı 32 yüksek lisans, 6 kısıtlı 19 doktora tez çalışması olmak toplamda 51 lisansüstü tez çalışmasına ulaşılmıştır. Ulaşılan yüksek lisans tezlerinden biri konuyla 
doğrudan alakalı olmasına rağmen hedef kitlesi örgün eğitim dışındaki gruplar olduğundan çalışma dışında bırakılmıştır.

\subsection{Verilerin Analizi ve Yorumlanması}

Araştırma kapsamında ulaşılan lisansüstü tezlerin araştırma soruları doğrultusunda incelenmesi amacıyla, tezlerin gerçekleştirildikleri yıl ve türlerini, temel alanlarını ve konu başlıklarını, hedef kitlelerini ve araştırma modellerini belirlemeye yönelik bir betimsel analiz formu hazırlanmıştır. Tezler, yüksek lisans ve doktora tezleri olarak iki gruba ayrılmış, araştırma soruları ve analiz formu doğrultusunda betimsel analize tabi tutulmuştur. Elde edilen veriler araştırma soruları doğrultusunda yorumlanmıştır.

\subsection{Sınırlılıklar}

Araştırma kapsamında tartışmalı ve sosyobilimsel konular başlıklarıyla Yükseköğretim Kurulu Ulusal Tez Merkezi internet sayfasında tarama yapılmış, eğitim bilimleri ve sosyal bilimler enstitülerinde gerçekleştirilen tüm lisansüstü tezler inceleme kapsamına alınmıştır. Ulaşılan tüm tezler 2007-2016 yılları arasını kapsadığından dolayı çalışma bu tarih aralığı ile sınırlandırıımıştır. Konu ile ilgili yazıımış olan makaleler araştırma kapsamı dışında tutulmuştur. Ayrıca anabilim dalı ve bilim dalı gibi sınıflamalar araştırmanın yapıldığı tarihteki adlandırmalar esas alınarak yapılmıştır.

\section{Bulgular}

\subsection{Birinci Araştırma Sorusuna İlişkin Bulgular}

“Türkiye' de tartışmalı ve sosyobilimsel konular üzerine gerçekleştirilen lisansüstü tezlerin yıllara, yüksek lisans ve doktora düzeyleri ile anabilim/bilim dallarına göre dağılımları nasıldır?" sorusuna yanıt aramak amacıyla 2007-2016 yılları arasında tartışmalı ve sosyobilimsel konular üzerine gerçekleştirilen tüm lisansüstü tezler araştırılmış ve sayısal olarak analizi yapılmıştır.

Tablo 1. Türkiye'de 2007-2016 Yılları Arasında Tartışmalı ve Sosyobilimsel Konular Üzerine Gerçekleştirilen Lisansüstü Tezlerin Yıllara, Yüksek Lisans ve Doktora Düzeyleri ile Anabilim (ABD) / Bilim Dallarına Göre Dağılımı

\begin{tabular}{|c|c|c|c|c|c|c|c|c|c|c|c|c|c|c|c|c|c|c|c|c|c|}
\hline \multirow[t]{2}{*}{$A B D$} & \multirow[t]{2}{*}{$\begin{array}{c}\text { Bilim } \\
\text { Dalı }\end{array}$} & \multicolumn{2}{|c|}{2007} & \multicolumn{2}{|c|}{2008} & \multicolumn{2}{|c|}{2009} & \multicolumn{2}{|c|}{2010} & \multicolumn{2}{|c|}{2011} & \multicolumn{2}{|c|}{2012} & \multicolumn{2}{|c|}{2013} & \multicolumn{2}{|c|}{2014} & \multicolumn{2}{|c|}{2015} & \multicolumn{2}{|c|}{2016} \\
\hline & & $Y$ & $D$ & $Y$ & $D$ & $Y$ & $D$ & $Y$ & $D$ & $Y$ & $D$ & $Y$ & $D$ & $Y$ & $D$ & $Y$ & $D$ & $Y$ & $D$ & $Y$ & $D$ \\
\hline iö & $\begin{array}{c}\text { Fen } \\
\text { bilgisi }\end{array}$ & 1 & - & - & 2 & 1 & - & 1 & 1 & 4 & 1 & 5 & 1 & 4 & - & 2 & 3 & 2 & 3 & 1 & 3 \\
\hline ī̈ & $\begin{array}{l}\text { Temel } \\
\text { eğitim }\end{array}$ & - & - & - & - & - & - & - & - & 1 & 1 & - & - & - & - & - & - & - & - & 1 & - \\
\hline iö & $\begin{array}{l}\text { Sosyal } \\
\text { bilgiler }\end{array}$ & - & - & - & - & 1 & - & - & - & - & - & - & - & - & - & - & - & 1 & - & - & - \\
\hline ОÖ & Biyoloji & - & - & - & - & - & 1 & - & - & 3 & - & - & - & - & - & 1 & 1 & 1 & - & - & 1 \\
\hline OÖ & Kimya & & & & & & & & & & & & & & & & & & & & \\
\hline
\end{tabular}


Şefika TATAR | Oktay Cem ADIGÜZEL

\begin{tabular}{|c|c|c|c|c|c|c|c|c|c|c|c|c|c|c|c|c|c|c|c|c|c|}
\hline & & - & - & - & - & 1 & - & - & - & - & - & - & - & - & - & 1 & - & - & - & - & - \\
\hline $\begin{array}{c}\text { Eğitim } \\
\text { Bilimleri }\end{array}$ & - & - & - & - & - & - & - & - & - & - & - & - & - & - & 1 & - & - & - & - & - & \\
\hline
\end{tabular}

Not: Tabloda yer alan “iö” ilköğretim sözcüğünün "OÖ” ortaöğretim sözcüğünün, "Y” yüksek lisans " $D$ ” ise doktora sözcüklerinin kısaltmasıdır.

Tablo 1'de görüldüğü gibi, tartışmalı konular üzerine gerçekleştirilen toplam 51 lisansüstü tez çalışmasına ulaşılmıştır. Bu tezlerin 32'sinin yüksek lisans, 19'unun ise doktora düzeyinde gerçekleştirilmiş olduğu belirlenmiştir. Tartışmalı ve sosyobilimsel konular üzerine gerçekleştirilen lisansüstü tezlerin anabilim dallarına göre dağılımı incelendiğinde 51 tezden 41'inin ilköğretim anabilim dalında yapılmış olduğu görülmektedir. İlköğretim anabilim dalında yapılmış 40 çalışmanın 36'sı fen bilgisi öğretmenliği, 3’ü sınıf öğretmenliği ve 2'si sosyal bilgiler öğretmenliği programına aittir. Bu çalışmaların 14'ü doktora 26'sı ise yüksek lisans tezidir. Ortaöğretim anabilim dalında ise toplamda 10 tez tamamlanmıştır. Bunların 3'ü doktora 7'si yüksek lisans tez çalışmasıdır. Ortaöğretim anabilim dalında yapılan 10 çalışmanın 8'i biyoloji öğretmenliği bilim dalına ve 2'si de kimya öğretmenliği bilim dalına aittir. Tartışmalı konular üzerine yapılan lisansüstü tez çalışmalarından sadece $1^{\prime}$ i eğitim bilimleri alanında gerçekleştirilmiştir. Yapılan toplam çalışmanın dörtte üçünden fazlasının ilköğretim anabilim dalında ve neredeyse tamamına yakınının da fen bilgisi öğretmenliği bilim dalında gerçekleştirilmiş olması tartışmalı ve sosyobilimsel konuların bu alandaki ağırlığını göstermektedir. Ortaöğretim anabilim dalında yapılan çalışmalar, toplamda yapılan çalışmaların 10'unu oluşturmakla birlikte bu çalışmalardan sadece 2'sinin kimya öğretmenliği programında geri kalanınsa biyoloji öğretmenliği programında gerçekleştirilmiş olması, tartışmalı ve sosyobilimsel konuların bu bilim dalındaki ağırlığını göstermektedir.

Tartışmalı ve sosyobilimsel konular üzerine gerçekleştirilen lisansüstü tezlerin yıllara göre dağılımı incelendiğinde, çalışmaların 2011 yılından sonra artış gösterdiği görülmektedir. 2007-2011 yılları arasında bu konularla ilgili en çok çalışma yapılan bilim dalı fen bilgisi öğretmenliği olmuştur. 2011 yılından önce sınıf öğretmenliği bilim dalı ve eğitim bilimleri anabilim dalında konuyla ilgili hiç çalışma yapılmamış ve 2011 yılında sonra bu iki alanda toplamda 4 çalışma yapılmış olduğu görülmektedir. Aynı şekilde kimya ve sosyal bilgiler öğretmenliği bilim dallarında 2011 yılından önce ve sonra birer çalışma yapılmış olduğu görülmektedir. 2011 yılından sonra tartışmalı ve sosyobilimsel konularla ilgili yazılan tezlerde artış olmakla birlikte tezlerin çoğunluğunun fen bilgisi öğretmenliği bilim dalında gerçekleştirildiği görülmektedir. Konuyla ilgili en çok tez 2011 ve 2014 yıllarında yazılmıştır. Yazılan yüksek lisans tezlerinin yıllara göre dağılımı incelendiğinde 2007-2016 yılları arasında 2008 yılı hariç her yıl en az bir çalışmanın yapıldığı görülmektedir. Doktora 
tezleri incelendiğinde, 2011 yılından sonra her yıl en az 1 çalışma yapıldığı ve konuyla ilgili doktora çalışmalarının bu yıldan sonra artış gösterdiği görülmektedir.

\section{2. İkinci Araştırma Sorusuna iliş̧kin Bulgular}

“Türkiye'de tartışmalı ve sosyobilimsel konular üzerine gerçekleştirilen lisansüstü tezlerin konu alanlarına ve hedef kitlelerine göre dağılımları nasıldır?" sorusuna yanıt aramak amacıyla Türkiye' de tartışmalı ve sosyobilimsel konular üzerine gerçekleştirilen tüm lisansüstü tezler konu alanlarına göre analiz edilmiştir.

Tablo 2. Türkiye'de Tartışmalı ve Sosyobilimsel Konular Üzerine Gerçekleştirilen Lisansüstü Tezlerin Konu Alanlarına Göre Dağılımı

\begin{tabular}{|c|c|c|c|c|c|c|c|c|c|c|c|c|c|c|c|c|c|c|c|c|}
\hline & $Y$ & $\bar{D}$ & $Y$ & $\bar{D}$ & $Y$ & $\bar{D}$ & $Y$ & $\bar{D}$ & $Y$ & $D$ & $Y$ & $\bar{D}$ & $Y$ & $\bar{D}$ & $\bar{Y}$ & $\bar{L}$ & & $\bar{D}$ & & $D$ \\
\hline $\begin{array}{l}\text { Tartışmalı/Sosyo bilimsel } \\
\text { konuların, öğrencilerin alan } \\
\text { bilgisi, muhakeme ve } \\
\text { argümantasyon yeteneği } \\
\text { üzerindeki etkisi }\end{array}$ & - & - & - & - & 2 & - & - & - & 1 & - & 1 & - & 1 & 1 & 3 & 1 & - & 1 & 1 & 3 \\
\hline $\begin{array}{l}\text { Tartışmalı/Sosyo bilimsel } \\
\text { konuların, öğretmen adaylarının } \\
\text { alan bilgisi, muhakeme ve } \\
\text { argümantasyon yeteneği } \\
\text { üzerindeki etkisi }\end{array}$ & - & - & - & 1 & - & - & - & - & 2 & - & 3 & 1 & - & - & - & 3 & - & - & & 2 \\
\hline $\begin{array}{l}\text { Öğretmen adaylarının } \\
\text { tartışmalı/sosyobilimsel } \\
\text { konularla ilgili tutum, özyeterlik } \\
\text { ve epistemolojik inançları }\end{array}$ & - & - & - & 1 & 1 & - & - & 1 & 2 & 1 & - & - & 2 & - & 1 & - & 1 & & & - \\
\hline $\begin{array}{l}\text { Öğrencilerin } \\
\text { tartışmalı/sosyobilimsel } \\
\text { konularla ilgili tutum ve } \\
\text { epistemolojik inançları }\end{array}$ & 1 & - & - & - & 1 & - & - & - & 1 & 1 & - & - & 1 & - & 1 & - & - & - & & - \\
\hline $\begin{array}{l}\text { Öğretmenlerin } \\
\text { Tartışmalı/sosyobilimsel } \\
\text { konularla ilgili tutum, özyeterlik } \\
\text { ve epistemolojik inançları }\end{array}$ & - & - & - & - & - & - & - & - & - & 1 & - & - & - & - & - & - & & 2 & & - \\
\hline $\begin{array}{l}\text { Biyoetik değer envanteri } \\
\text { geliştirilmesi }\end{array}$ & - & - & - & - & - & 1 & - & - & 1 & . & - & - & & - & - & - & - & - & - & - \\
\hline
\end{tabular}

Tablo 2'de belirtildiği gibi, tartışmalı ve sosyobilimsel konular üzerine yapılan lisansüstü çalışmaların 6 farklı konu alanında gerçekleştirildiği görülmektedir. Bu konularda yapılan tez çalışmalarının konu alanlarına göre dağılımları incelendiğinde; tartışmalı/sosyobilimsel konuların alan bilgisi, muhakeme ve argümantasyon yeteneği üzerindeki etkisine yönelik olarak gerçekleştirilen tezlerin, bu konularla ilgili bitirilen 
tezlerin yarısından fazlasını oluşturduğu görülmektedir. Bu konuyu sayıca yine büyük çoğunluğu oluşturan tartışmalı/sosyobilimsel konularla ilgili tutum, özyeterlik ve epistemolojik inançlar konusu takip etmektedir. Bu iki ana konu haricinde bir diğer başlık ise biyoetik değer envanteri geliştirilmesi konusudur.

Tartışmalı ve sosyobilimsel konuların, alan bilgisi, muhakeme ve argümantasyon yeteneği üzerindeki etkisi konusuna yönelik 28 lisansüstü çalışma yapıldığı ve bu çalışmaların, öğrenciler ve öğretmen adayları olmak üzere iki farklı hedef kitlede ele alındığı görülmektedir. Tartışmalı/sosyobilimsel konuların "öğrencilerin" alan bilgisi, muhakeme ve argümantasyon yeteneği üzerindeki etkisiyle ilgili incelenen tezlerde öne çıkan başlıca konuların; biyoçeşitlilik, yerel sosyobilimsel konular (bölgede bulunan sulama göleti, tavuk kümesi, baz istasyonu, vb.), genetik, maddenin yapısı, dengeli beslenme, klonlama, kök hücre, genom projesi, biyoteknoloji, genetiği değiştirilmiş organizmalar, küresel ısınma, enerji tasarrufu, nükleer enerji, organ bağışı olduğu ve tezlerin çoğunda bahsi geçen konulardan sadece birinin ele alındığı görülmüştür. Tartışmalı/sosyobilimsel konuların öğrenmedeki etkisinin incelenmesinde en çok kullanılan yöntem ise argümantasyon yöntemi olmuştur.

Tartışmalı/sosyobilimsel konuların öğretmen adaylarının alan bilgisi, muhakeme ve argümantasyon yeteneği üzerindeki etkisinin incelendiği tezlerde öne çıkan başlıca sosyobilimsel konuların, GDO, biyolojik çeşitlilik, küresel ısınma, hava kirliliği, gıda katkı maddeleri, alternatif enerji kaynakları, iklim değişikliği, endüstri devrimi, klonlama, nükleer enerji santralleri, çevre sorunları, genetik tarama testi olduğu görülmüştür. Öğretmen adayları ile yapılan çalışmaların tamamına yakınının fen bilgisi öğretmen adayları ile ilgili olduğu ve geri kalan az sayıda çalışmanın da biyoloji öğretmen adaylarıyla yapıldığı saptanmıştır.

Tartışmalı ve sosyobilimsel konularla ilgili tutum, özyeterlik ve epistemolojik inançlar konusunda 21 lisansüstü çalışma yapıldığı ve bu çalışmaların; öğretmen, öğretmen adayları ve öğrenciler olmak üzere üç farklı hedef kitlede ele alındığı görülmektedir. Bu hedef kitleler arasında hakkında en fazla çalışma yapılanı öğretmen adayları olurken onları öğrenciler ve öğretmenler takip etmiştir.

Tartışmalı ve sosyobilimsel konularla ilgili bir diğer konu başlığı biyoetik değer envanteri geliştirilmesidir. Bu konuyla ilgili ilk çalışma bir doktora tezi, daha sonraki ise bir yüksek lisans tezidir. Önce yapılanın bir doktora tezi olduğu düşünüldüğünde, sonradan yapılan yüksek lisans çalışmasının bir tekrar çalışması olduğu görülmektedir. Tartışmalı ve sosyobilimsel konularla ilgili değer envanteri geliştirme çalışmalarının sadece biyoetikle ve sadece ortaöğretimle sınırlı kaldığı görülmektedir. 
Tablo 3. Türkiye'de Tartışmalı ve Sosyobilimsel Konular Üzerine Gerçekleştirilen Lisansüstü Tezlerin Hedef Kitlelerine Göre Dağılımı

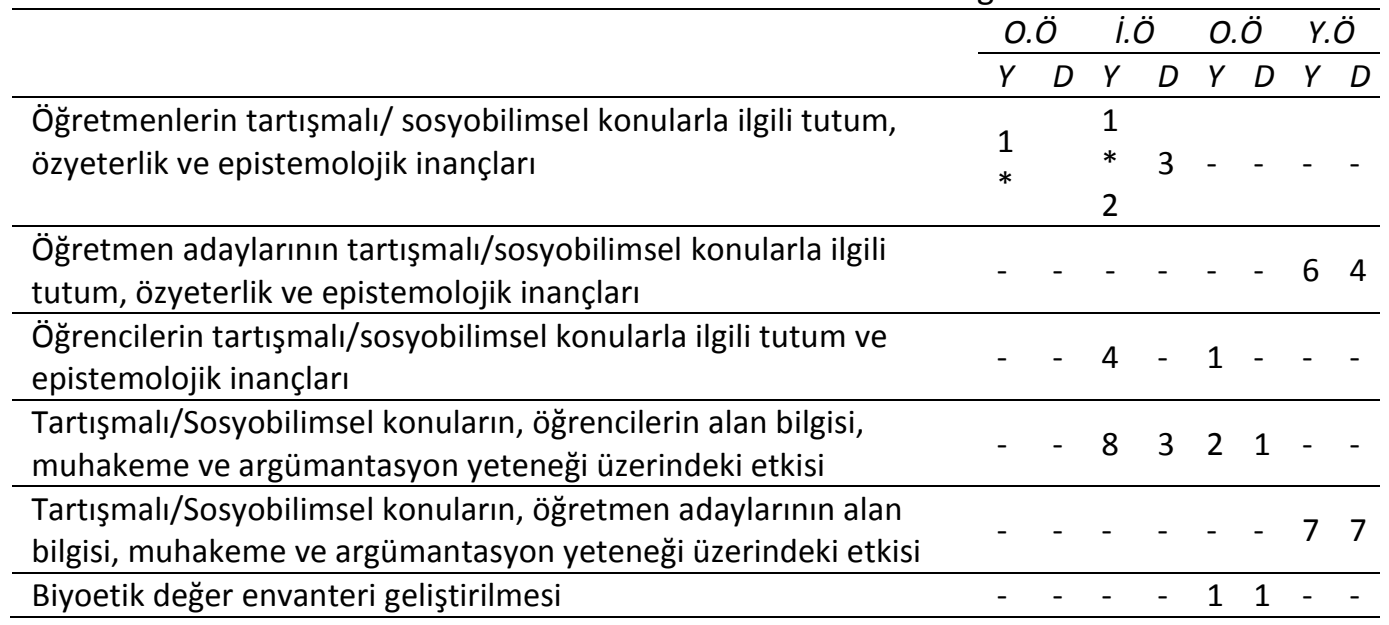

Not. Tabloda (*) simgesiyle belirtilen yüksek lisans çalışmalarından bir tanesi hem okul öncesi hem de ilköğretim seviyelerini kapsamaktadır.

Gerçekleştirilen tezler incelendiğinde tezlerin 27'sinin ilk ve ortaöğretim düzeyine, 24'ünün yükseköğretim düzeyine ait olduğu görülmektedir. Tezlerden sadece bir tanesi okul öncesi ve ilköğretimi birlikte kapsamaktadır. Onun haricinde okul öncesinde konuyla ilgili yapılmış çalışma bulunmamaktadır. Bu durum, tartışmalı ve sosyobilimsel konuların okul öncesi dönemle ilişkilendirilmediğini göstermektedir. İlköğretim düzeyinde yapılan çalışmalar 15 yüksek lisans 6 doktora olmak üzere 21, ortaöğretim düzeyinde yapılan çalışmalar ise 4 yüksek lisans 2 doktora olmak üzere 6 tanedir.

Öğretmenlere benzer şekilde öğrencilerin tartışmalı ve sosyobilimsel konularla ilgili tutum ve epistemolojik inançları konusu da sadece 1 yüksek lisans teziyle ortaöğretimde kendine yer bulabilmiştir. İlköğretim düzeyinde de konuyla ilgili yapılan yüksek lisans çalışması sayısı sadece 4'tür. Öğretmen adaylarının tartışmalı ve sosyobilimsel konularla ilgili bilgi, tutum, özyeterlik ve epistemolojik inançları konusunda 6 yüksek lisans 4 doktora olmak üzere 10 çalışma yapıldığı görülmektedir. Bilgi, tutum, özyeterlik ve epistemolojik inançlar başlığı altında hakkında en fazla çalışma yapılan hedef kitle öğretmen adayları olmuştur.

Tartışmalı ve sosyobilimsel konuların, öğretmen adaylarının alan bilgisi, muhakeme ve argümantasyon yeteneği üzerindeki etkisi konusunda 7 yüksek lisans 7 doktora olmak üzere 14 çalışma yapılmıştır. Bu konuda yapılan doktora çalışmalarının sayıca yüksek lisans çalışmalarına eşit olması, konunun kapsamlı ve derinlemesine çalışılmış olduğunu göstermektedir. Tartışmalı ve sosyobilimsel konuların öğrencilerin alan bilgisi, muhakeme ve argümantasyon yeteneği üzerindeki etkisi konusunda ilköğretimde 8 yüksek lisans 3 
Şefika TATAR | Oktay Cem ADIGÜZEL

doktora, ortaöğretimde 2 yüksek lisans 1 doktora çalışması yapılmıştır. Her iki seviyede de doktora çalışması sayısı az olmakla birlikte, ortaöğretimde yapılan çalışmaların sayıca azlığı dikkat çekicidir.

Biyoetik değer envanteri geliştirilmesi konusunda 1 yüksek lisans, 1 doktora tezi bulunmaktadır. Bu tezlerden her ikisi de ortaöğretim öğrencilerine yönelik biyoetik değer envanteri geliştirilmesi ile ilgilidir.

\section{3. Üçüncü Araştırma Sorusuna iliş̧kin Bulgular}

“Türkiye'de tartışmalı ve sosyobilimsel konular üzerine gerçekleştirilen lisansüstü tezlerin araştırma modellerine göre dağılımı nasıldır? sorusuna yanıt aramak amacıyla Türkiye'de tartışmalı ve sosyobilimsel konular üzerine gerçekleştirilen tüm lisansüstü tezler araştırma modellerine göre analiz edilmiştir.

Tablo 4. Türkiye'de Tartışmalı ve Sosyobilimsel Konular Üzerine Gerçekleştirilen Lisansüstü Tezlerin Araştırma Modellerine Göre Dağılımı

\begin{tabular}{|c|c|c|c|c|c|c|c|c|c|c|c|}
\hline & $\begin{array}{l}\bar{\varpi} \\
\grave{े} \\
\bar{\Xi}\end{array}$ & $\begin{array}{l}0 \\
\frac{1}{0} \\
\vdots \\
\circ\end{array}$ & 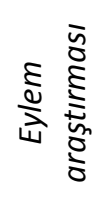 & 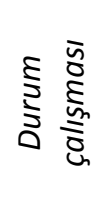 & $\begin{array}{l}\text { ¿े } \\
\frac{1}{\vdots} \\
\frac{1}{2}\end{array}$ & 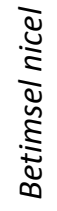 & 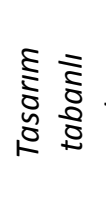 & 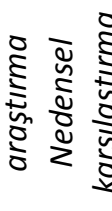 & 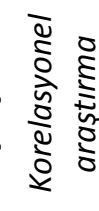 & 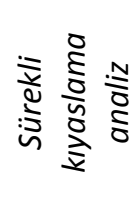 & $\stackrel{N}{=}$ \\
\hline$Y$ & 10 & 7 & 1 & 1 & 8 & 3 & - & - & 1 & - & - \\
\hline D & 1 & 4 & 2 & $5+1 *$ & $3+1 *$ & & 1 & 1 & - & 1 & 1 \\
\hline
\end{tabular}

Not. $\left(^{*}\right)$ simgesiyle gösterilen doktora tezlerinden bir tanesi hem durum çalışması hem de karma modelde desenlenmiştir.

Tablo 4'te belirtildiği gibi, Türkiye'de tartışmalı ve sosyobilimsel konular üzerine gerçekleştirilen lisansüstü tezlerin araştırma modellerine göre dağılımı incelendiğinde bitirilen 51 tezin büyük bir kısmının karma, deneysel ve tarama modellerinde desenlendiği görülmektedir. Yüksek lisans düzeyinde gerçekleştirilen 31 tezin 10'u deneysel model, 8'i karma, 7'si tarama modeli, 3'ü betimsel nicel, biri eylem araştırması, biri durum çalışması ve biri korelasyonel araştırma olarak desenlenmiştir.

Doktora düzeyindeki çalışmalara bakıldığında ise deneysel model bir kez kullanılmıştır. 4 doktora tezi ise tarama modelinde gerçekleştirilmiştir. Diğer doktora tezlerinden 6'sı durum çalışması, 4'ü karma, 2'si eylem araştırması, 1'i tasarım tabanlı, 1'i nedensel karşılaştırma, 1’i sürekli kıyaslamalı analiz ve 1 'i de belirsizdir. 


\section{Sonuç, Tartışma ve Öneriler}

Bu çalışma kapsamında 2007-2016 yılları arasında tartışmalı ve sosyobilimsel konular üzerine gerçekleştirilmiş lisansüstü tez çalışmalarının incelenerek, bu konuların ağırlıklı olarak hangi anabilim/bilim dalları tarafından araştırma konusu yapıldığının saptanması ve bu anabilim/bilim dalları içerisinde eğitim bilimleri alanında gerçekleştirilen araştırmaların durumunun betimlenmesi amaçlanmıştır. Bu amaç doğrultusunda tezlerin yıllara göre dağılımı incelendiğinde, 2011 yılından önce tartışmalı ve sosyobilimsel konular üzerine 4 doktora tezinin bulunması bu alandaki eksikliği göstermektedir. Yüksek lisans tez sayısının doktora tez sayısının neredeyse 2 katı olması tartışmalı ve sosyobilimsel konuların daha çok yüksek lisans düzeyinde çalışılmaya uygun bir konu olarak algılandığını düşündürmektedir. Doktora çalışmalarının yüksek lisans çalışmalarına göre daha geniş kapsamlı ve çok yönlü çalışmalar olduğu düşünüldüğünde bu çalışmaların alana katkısı bakımından daha çok olması arzu edilen bir durumdur. Ancak, dokuz yıl içerisinde bu konuda yapılan doktora çalışmalarının sayısının sadece 19 olması dolayısıyla bu konu alanı için doktora tezlerinin sayıca yetersiz olduğu söylenebilir.

Tartışmalı ve sosyobilimsel konular üzerine yazılan tezlerin tamamına yakınının fen bilgisi, kimya ve biyoloji bilim dallarına ait olması, daha çok sosyobilimsel ve biyoetik tartışmalar üzerine odaklanıldığını göstermektedir. Ayrıca, tartışmalı konular üzerine yazılan 51 tezden 41'inin ilköğretim bilim dalında gerçekleştirilmiş olması, bu konuların daha çok temel eğitim basamağında ele alınması gerektiğinin düşünüldüğünü ortaya koymaktadır. Tartışmalı ve sosyobilimsel konularla ilgili yapılmış olan çalışmaların fen bilgisi öğretmenliği bilim dalında yoğunlaşması ve sayıca çok olmasının sebebi olarak 2000 yılından sonra fen öğretim programlarına kazanım olarak giren FTT ve 2013 yılından sonra programlara giren FTTÇ yaklaşımı gösterilebilir. Her iki yaklaşım da fen ve teknolojideki gelişmelerin sosyal ve etik boyutuna odaklanarak bu alandaki tartışmalı sosyobilimsel konulara dikkat çekmektedir. Buna rağmen, fen öğretimi alanında Türkiye'deki geçmişi 2000 yılına kadar uzanan sosyobilimsel konuların, lisansüstü düzeyde çalışılmaya 2007 yılından sonra başlanması ve yoğun olarak çalışılmasının 2011 yılını bulmasının, bu konulara fen bilgisi öğretim programlarında çok sınırlı ve yüzeysel olarak yer verilmesinden kaynaklanmış olabileceği düşünülmektedir. Tartışmalı konular, ilköğretim sosyal bilgiler öğretim programına 2005-2006 yapılandırmacılık felsefesine dayalı programlarla birlikte girmiştir. Ancak, 2005 yılında uygulanmaya başlanan 4-8. sınıf sosyal bilgiler öğretim programında, sadece iki yerde tartışmalı konulara değinilmektedir. Tartışmalı konuların sosyal bilgiler dersi boyutuyla ilgili yapılan lisansüstü tez çalışmalarının sayıca azlığı buna dayanarak açıklanabilir. Eğitim bilimleri anabilim dalında tartışmalı ve sosyobilimsel konulara ilişkin sadece bir lisansüstü çalışmanın yapılmış olması ve söz konusu çalışmanın yine bu konuların fen ve teknoloji boyutunu vurgulaması, eğitim bilimleri anabilim dalında tartışmalı konularla ilgili bir eksikliği ortaya koymaktadır. 
Tartışmalı ve sosyobilimsel konular üzerine yazılan lisansüstü tezlerde bu konularla öğretimin öğrencilerin bilişsel düşünme becerileri ve başarı düzeyi üzerinde anlamlı bir farklılığa yol açtığı (Deveci, 2009); kavram öğrenmelerine ve karar verme becerilerinin gelişmesine olumlu etkisi olduğu bulunmuştur (Goloğlu, 2009; Topaloğlu, 2016). Sosyobilimsel konularda bilimsel tartışma destekli öğretimin, öğrencilerin fen okuryazarlıklarını, bilimsel tartışmaya eğilimlerini, bilim-toplum sorunlarına duyarlılıklarını ve karar verme becerilerini geliştirmede etkili olduğu sonucuna varılmıştır (Gülhan, 2012). Sosyobilimsel konularla öğretimle öğrencilerde argümantasyon becerisinin geliştirilebildiği ve üretilen argümanların kalitesinde olumlu yönde bir değişim meydana geldiği görülmüştür (Öztürk, 2013; Sevgi, 2016). Tartışmalı ve sosyobilimsel konuların öğrencilerin alan bilgisi, muhakeme ve argümantasyon yeteneği üzerindeki etkisi konusunda ilköğretimde 8 yüksek lisans 3 doktora, ortaöğretimde 2 yüksek lisans 1 doktora çalışması yapılmıştır. Her iki seviyede de doktora çalışması sayısı az olmakla birlikte, ortaöğretimde yapılan çalışmaların sayıca azlığı dikkat çekicidir. Oysa yaş grubu ve bilişsel olgunluk olarak ortaöğretimdeki öğrenciler bu konularda daha net veri elde edilebilecek bir grubu oluşturmaktadır. Bu konudaki araştırmaların neden daha çok ilköğretime odaklandığı merak uyandırmaktadır. Ayrıca, tartışmalı ve sosyobilimsel konuların ilköğretim ve ortaöğretimdeki öğrencilerin alan bilgisi, muhakeme ve argümantasyon yeteneği üzerindeki etkisini inceleyen çalışmaların öğretmen adaylarıyla ilgili çalışmalardan az olması bu konuların öğrenilmesinin aslında hangi hedef kitle ve hangi düzey için daha önemli olması gerektiği konusunda çelişki yaratmaktadır.

İncelenen tezlerde öğrencilere benzer şekilde öğretmen adaylarının da bu konularla öğretim sonucunda sosyobilimsel muhakeme yeteneklerinde gelişme olduğu saptanmıştır (Cansız, 2014). Toplum bilimsel konuların öğrenilmesinde argümantasyon tabanlı öğrenme etkinliklerinin öğretmen adaylarının öğrenme sürecinde etkili olduğu sonucuna ulaşılmıştır (Domaç, 2011). Farklı sosyobilimsel konuların ele alındığı sorgulayıcı öğretime dayalı derslerde öğretmen adaylarının yansıtıcı muhakeme becerileri ve argümantasyon yeteneklerinde artış gözlenmiştir (Karışan, 2014). Alan bilgisi düzeyinin, sosyobilimsel argümantasyon kalitesine etkisinin incelendiği çalışmalarda alan bilgisinin argümantasyon kalitesi ve informal akıl yürütme örüntülerinin üzerinde birincil düzeyde etkili olmadığı sonucuna ulaşılmıştır (Kutluca, 2012; Soysal, 2012; Urhan, 2016; Yaman, 2011). Bununla birlikte öğretmen adaylarının kritik düşünme niteliklerinin, sosyobilimsel konuların içeriğinden bağımsız olduğu ancak kişisel deneyimler, sosyal faktörler, ahlaki etik konular ve teknolojiden duyulan endişelerden etkilendiği (Topçu, 2008); adaylarda sosyal ve ekoloji odaklı informal muhakeme biçimlerinin daha ağır bastığı görülmüştür (Sağlam, 2016). Tartışmalı ve sosyobilimsel konuların, öğretmen adaylarının alan bilgisi, muhakeme ve argümantasyon yeteneği üzerindeki etkisi konusunda 7 yüksek lisans 7 doktora olmak üzere 14 çalışma yapılmıştır. Bu konuda yapılan doktora çalışmalarının sayıca yüksek lisans çalışmalarına eşit olması, konunun kapsamlı ve derinlemesine çalışılmış olduğunu 
göstermektedir. Ancak geleceğin uygulayıcısı olacak öğretmen adaylarına yönelik çalışmaların, öğretmen adaylarının tartışmalı ve sosyobilimsel konularla ilgili tutum ve inançları yerine muhakeme ve argümantasyon yeteneğine odaklanması, araştırmaların işlevselliği ve uygulamaya katkısı bakımından düşündürücüdür.

Tartışmalı ve sosyobilimsel konularla öğretimin öğrencilerin ve öğretmen adaylarının alan bilgisi, muhakeme ve argümantasyon yeteneği üzerindeki etkisi tüm bu çalışmalarla ortaya koyulmuşken, bu konuların sınıf içinde aktif uygulayıcısı olan öğretmenler ve onların hedef kitlesi olan öğrencilerle ilgili yapılan çalışmaların sayıca çok az olması, örgün eğitimde tartışmalı ve sosyobilimsel konulara ilişkin var olan durumun betimlenmesi açısından yetersiz kalmaktadır. Diğer taraftan, gelecekte uygulayıcı olacak öğretmen adaylarına yönelik çalışmaların ilk sırada yer alması, bu konularla ilgili öğretmen adayları arasında farkındalık yaratması ve bilinç uyandırması açısından ve öğretmen eğitim programlarında tartışmalı ve sosyobilimsel konulara hak ettiği yerin verilmesi açısından önemli görünmektedir.

Öğretmen adaylarının tartışmalı/sosyobilimsel konularla ilgili tutum, özyeterlik ve epistemolojik inançları üzerine yapılan araştırma sonuçlarına göre öğretmen adayları, bu konuların nasıl öğretilebileceği konusunda gerekli bilgi, yöntem ve teknikler açısından yeterince fikir sahibi değildir (Akşit, 2011). Öğretmen adayları, sosyobilimsel konuların öğretiminde kendilerini yetersiz görmekte ve bu konularda eğitim görmelerinin gerekliliğine inanmaktadırlar (Akşit, 2011; Bakar, 2010; Sürmeli, 2008). Öğretmen adaylarının sahip oldukları öz yeterliliğin epistemolojik inançlardan (Baltacı, 2013) ve eğitim gördükleri lisans programında bu konulara ne kadar yer verildiğinden etkilendiği (Akşit, 2011) gözlenmiştir. Ayrıca öğretmen adaylarının sosyobilimsel konularda genel olarak sınırlı bilgiye sahip oldukları (Akşit, 2011; Saylan, 2014; Sürmeli, 2008; Yüce, 2011) ve bu konuların içeriğine bağlı olarak öz yeterliliklerinin orta, risk algılarının yüksek düzeyde olduğu ve bu konular hakkında olumsuz tutuma sahip oldukları görülmüştür (Sönmez, 2011; Sürmeli, 2008; Yüce, 2011). İlköğretim öğretmen adaylarının, ortaöğretim öğretmen adaylarına göre tartışmalı konuların öğretimine daha olumlu yaklaşması da bir diğer önemli araştırma sonucudur (Seçgin, 2009). Öğretmen adaylarının tartışmalı ve sosyobilimsel konularla ilgili bilgi, tutum, özyeterlik ve epistemolojik inançları konusunda 6 yüksek lisans 4 doktora olmak üzere 10 çalışma yapıldığı görülmüştür. Bilgi, tutum, özyeterlik ve epistemolojik inançlar başlığı altında hakkında en fazla çalışma yapılan hedef kitle öğretmen adayları olmuştur. Gelecekte uygulayıcı olacak öğretmen adaylarının tartışmalı ve sosyobilimsel konularla ilgili bilgi, tutum, özyeterlik ve epistemolojik inançlarına yönelik çalışmaların diğer hedef kitlelerle kıyaslandığında görece çok olmasının gelecekteki öğretmen yeterlilikleri açısından olumlu olduğu düşünülmektedir.

Öğretmenlerin tartışmalı/sosyobilimsel konularla ilgili tutum, özyeterlik ve epistemolojik inançları üzerine yapılan araştırma sonuçlarına göre öğretmenler bu konuların öğretiminde; kişisel inanç sistemleri, motivasyon, deneyim (Karahan, 2015), 
Şefika TATAR | Oktay Cem ADIGÜZEL

alışkanlıklar ve kültürel faktörler (Sönmez, 2015) ile toplumsal risk algılarından etkilenmekte ve bu konuların öğretiminde kendilerini yetersiz görmektedirler (Çopur, 2015; Gözüm, 2015; Koçyiğit, 2015). Öğretmenler sosyobilimsel konularla ilgili yetersizliklerinin eğitim sistemindeki aksaklıklar, öğretim programı ve ders kitaplarındaki yetersizlikler, öğrenciler, aileler, destekleyici materyaller ve okul olanaklarından kaynaklandığını düşünmektedirler (Çopur, 2015; Karahan, 2015; Özden, 2011; Sönmez, 2015). Öğrencilerin gelişimsel seviyelerine uygun olan tartışmalı konular sınıf ortamına getirildiğinde öğrencilerin üst düzey düşünme ve iletişim gibi kritik beceriler edinmesine katkı sağladığı (Çopur, 2015), bilim ve bilimsel yöntemle ilgili algılarının sosyobilimsel temelli derslerden etkilendiği (Karahan, 2015) öğretmenler tarafından ifade edilmektedir. Öğretmenlerin tartışmalı ve sosyobilimsel konularla ilgili tutum, özyeterlik ve epistemolojik inançlarının öğretim etkinliklerini etkilediği görülürken bu konuya yönelik çalışmaların sadece ilköğretim seviyesiyle sınırlı kalmış olması dikkat çekicidir. Bu durum, bu konuların sadece ilköğretim seviyesinde ele alınıyormuş gibi algılandığını ortaya koymaktadır. Oysa bu konular ortaöğretim düzeyinde tarih, coğrafya, fizik, kimya, biyoloji gibi birçok dersin konu alanına girmektedir. Ayrıca her düzeyden öğretmenin tartışmalı ve sosyobilimsel konularla ilgili tutum ve inançlarıyla bu konuları ele alırken yaşadığı zorluklar bu konuların uygulamadaki yerine ışık tutacak en önemli kaynaktır. Bu sebeple öğretmenlere yönelik yapılan çalışmaların arttırılması gerektiği düşünülmektedir.

Öğrencilerin tartışmalı/sosyobilimsel konularla ilgili tutum ve epistemolojik inançları üzerine yapılan araştırma sonuçlarına göre, bu konularla öğretim yapılan öğrencilerde bu konulara ilişkin farkındalık artmış ve içerik bilgisi de bu durumdan olumlu yönde etkilenmiştir (Şahintürk, 2014; Taşpınar, 2011). Ayrıca sofistike inanışa sahip öğrencilerin bu konularda daha kapsamlı ve gelişmiş görüşe sahip oldukları ortaya çıkmıştır (Çavuş, 2013). Öğrencilerin bu konularla ilgili etik algılarının başarı ve sosyoekonomik düzeylerinden etkilendiği görülmüştür (Karakaya, 2011). Öğretmenlere benzer şekilde öğrencilerin tartışmalı ve sosyobilimsel konularla ilgili tutum ve epistemolojik inançları konusu da sadece 1 yüksek lisans teziyle ortaöğretimde kendine yer bulabilmiştir. İlköğretim düzeyinde de konuyla ilgili yapılan yüksek lisans çalışması sayısı sadece 4'tür. $\mathrm{Bu}$ durum, tartışmalı ve sosyobilimsel konuların sınıfa getirilişinde ve sınıfta ele alınmasında öğrenci etkisini açıklamakta ve ortaya koymakta bir yetersizlik olduğunu göstermektedir. Oysa bu konuların sınıfta ele alınmasında en önemli etmenlerden birisi de öğrencilerin bu konularla ilgili tutum ve inançlarıdır.

Yapılan çalışmalar incelendiğinde tartışmalı ve sosyobilimsel konuların alan bilgisi, muhakeme ve argümantasyon yeteneği üzerindeki etkisi ve bu konularla ilgili tutum, özyeterlik ve epistemolojik inançlar olmak üzere iki ana konu başlığının ön plana çıktığı görülmektedir. Tartışmalı ve sosyobilimsel konuların alan bilgisi, muhakeme ve argümantasyon yeteneği üzerindeki etkisi konusunda yapılan çalışmalar, tutum, 
özyeterlik ve inançlarla ilgili yapılan çalışmalardan fazladır. Yapılan lisansüstü çalışmaların, bu konuların daha çok bilişsel boyuttaki etkisine odaklandığı görülmektedir. Oysa tutum, özyeterlik ve inanç gibi duyuşsal boyutlar bu tür konuların öğrenilmesinde ya da öğretilmesinde çok daha büyük etkiye sahiptir. Bu nedenle, konunun duyuşsal boyutuna ilişkin çalışmaların arttırılması gerektiği düşünülmektedir. Ayrıca, konuyla ilgili alan bilgisi, muhakeme ve argümantasyon yeteneği sorgulanan hedef kitlenin ilköğretim ve yükseköğretimle sınırlı kalması, ortaöğretimin neredeyse yok sayılması da bu eğitim kademesinde daha fazla lisansüstü çalışmaya ihtiyaç duyulduğunu ortaya koymaktadır. Tartışmalı ve sosyobilimsel konularla ilgili yapılan lisansüstü çalışmaların tamamının fen bilgisi, biyoloji, kimya, sosyal bilgiler gibi sadece belli bir disipline ve hatta o disiplin içinde sadece belli bir konuya (GDO, nükleer santral, klonlama) yönelik olarak gerçekleştirildiği görülmektedir. Bu konulara ilişkin tutum, özyeterlik, epistemolojik inançlar ve bu konuların muhakeme yeteneği üzerindeki etkisinin dışında bu konuların bahsi geçen disiplinlerin öğretim programlarındaki yeri, kapsamı ve ele alınış biçimine yönelik herhangi bir çalışma yapılmamış olması bu konulara ilişkin daha kapsamlı çalışmalar yapılması gerekliliğini ortaya koymaktadır.

Tartışmalı ve sosyobilimsel konular, lisansüstü çalışmaların incelenmesi sonucunda ortaya çıktığı gibi sadece fen bilimleri ya da sosyal bilimlerin değil tüm disiplinlerin konu alanına girebilecek niteliktedir. Ancak incelenen lisansüstü çalışmaların çoğunluğunun ilköğretim anabilim dalı ve fen bilgisi bilim dalında yapıldığı görülmektedir. Çalışmaların tamamına yakınının fen bilimleri kapsamındaki disiplinlerle ilişkili olması, Türkiye'de tartışmalı konular denince akla sadece sosyobilimsel konular geldiği izlenimini uyandırmaktadır. Diğer yandan tartışmalı konuların sosyal bilimlerle ilgili boyutunda yok denecek kadar az çalışma yapılmış olması, bu konunun eğitsel öneminin henüz kavranamadığını ortaya koymaktadır. Ayrıca, yapılan çalışmaların neredeyse tamamına yakınının ilköğretim ve yükseköğretim kademesinde olması bu konuların okul öncesi ve ortaöğretimle ilişkilendirilmediğini ortaya koymaktadır.

Tartışmalı ve sosyobilimsel konularla ilgili yapılan lisansüstü çalışmaların çoğunluğu tarama, karma ve deneysel modelde gerçekleştirilmiş ve veri toplama teknikleri bakımından zengin çalışmalardır. Veri toplama teknikleri incelendiğinde çalışmaların çoğunda nitel ve nicel tekniklerin bir arada kullanıldığı görülmektedir. Bu bakımdan konuyla ilgili yapılan hem yüksek lisans hem de doktora çalışmalarının birçoğunun detaylı olduğunu söylemek mümkündür. Ancak bu çalışma, Türkiye'de tartışmalı ve sosyobilimsel konular üzerine gerçekleştirilen lisansüstü çalışmaların konu ve sayı bakımından çok sınırlı olduğunu ortaya koymuştur. Doktora tezlerinin daha kapsamlı, ayrıntılı ve özgün olduğu varsayımından hareketle bu konuda yazılan doktora tezlerinin çok az sayıda kalması yapılan çalışmaların hem nitelik hem nicelik olarak sınırlı olduğunu düşündürmektedir. Bu sebeple konuyla ilgili doktora düzeyinde daha fazla çalışma yapılmasına ihtiyaç duyulmaktadır. 
Şefika TATAR | Oktay Cem ADIGÜZEL

Türkiye'de tartışmalı ve sosyobilimsel konular üzerine gerçekleştirilen lisansüstü çalışmaları inceleyen bu çalışma sonucunda, bu konuda gelecekte yapılacak çalışmalar için aşağıdaki öneriler getirilebilir:

- Tartışmalı konularla ilgili bilimsel çalışmalar, fen bilimlerinin dışındaki diğer disiplin alanlarına yayılarak arttırılabilir.

- Tartışmalı ve sosyobilimsel konuların araştırılması sadece ilköğretim ve yükseköğretimle sınırlı kalmayıp okul öncesi ve ortaöğretimde de bu konulara gereken önem verilebilir.

- Konuyla ilgili gerçekleştirilen ortaöğretim biyoetik değer envanteri geliştirme çalışmaları sadece biyoetikle ve sadece ortaöğretimle sınırlıdır. Benzer çalışmalar ilköğretim ve yükseköğretimde biyoetikten farklı tartışmalı konular için de genişletilerek yapılabilir.

- Tartışmalı ve sosyobilimsel konuların ele alınmasında önemli paydaşlar olan öğretmen ve öğrencilere ilişkin gerçek resmi ortaya koyan boylamsal çalışmalar yapılabilir.

- Yapılan lisansüstü çalışmalar konunun tutum, özyeterlik, inanç gibi duyuşsal boyutuyla muhakeme ve argümantasyon yeteneği gibi bilişsel boyutuna odaklanmıştır. Bu konuların ele alınmasında en önemli etmenlerden biri olan eğitim/öğretim programı boyutuyla ilgili hiç çalışma yapılmamıştır. Bu sebeple tartışmalı ve sosyobilimsel konuların eğitim/öğretim programı boyutuyla ilgili de çalışmalar yapılabilir.

\section{Kaynaklar}

Akşit, A. C. A. (2011). Sınıf öğretmeni adaylarının sosyobilimsel konularla ve bu konuların öğretimiyle ilgili görüşleri. Yayımlanmamış Yüksek Lisans Tezi. İzmir: Ege Üniversitesi, Sosyal Bilimler Enstitüsü.

Bakar, E. (2010). Fen bilgisi öğretmen adaylarının biyoetik eğitimiyle ilgili uygulama ve görüşlerinin değerlendirilmesi. Yayımlanmamış Doktora Tezi. Ankara: Gazi Üniversitesi, Eğitim Bilimleri Enstitüsü.

Baltacı, S. (2013). Fen ve teknoloji ögrretmen adaylarının sosyobilimsel bir konudaki (Gdo'lu besinler) öğretim öz yeterlilikleri ve bu yeterliliklerin epistemolojik inançlar ile ilişkileri. Yayımlanmamış Yüksek Lisans Tezi. Bolu: Abant İzzet Baysal Üniversitesi, Eğitim Bilimleri Enstitüsü.

Bohan, C. H. \& Feinberg, J. R. (2008). The authors of the Harvard social studies project: a retrospective analysis of Donald Oliver, Fred Newmann, and James Shaver. Social Studies Research and Practice, 3(2), 54-67. 
Cansız, N. (2014). Developing preservice science teachers' socioscientific reasoning through socioscientific issues-focused course. Yayımlanmamış Doktora Tezi. Ankara: Ortadoğu Teknik Üniversitesi, İlköğretim Bölümü.

Claire, H. \& Holden, C. (2007). The challenge of teaching controversial issues. England: Trentham.

Curriculum Standing Committee of National Education Professional Associations [CSCNEPA], (2007). Developing a twenty-first century school curriculum for all Australian students. A working paper prepared for the Curriculum Standing Committee of National Education Professional Associations. http://www.acsa.edu.au/pages/images/cscnepa_paper_june087.pdf (Erişim tarihi: 03.05.2016).

Çatak, M. (2015). Türkiye'de sosyal bilgiler eğitim programlarının incelenmesi. EKEV AKademi Dergisi, 62, 69-94.

Çavuş, R. (2013). Farklı epistemolojik inanışlara sahip 8. sınıf öğrencilerinin sosyobilimsel konulara bakış açıları. Yayımlanmamış Yüksek Lisans Tezi. Sakarya: Sakarya Üniversitesi, Eğitim Bilimleri Enstitüsü.

Çopur, A. (2015). Sosyal bilgiler öğretmenlerinin tartışmalı konuların öğretimine ilişkin düşüncelerinin incelenmesi. Yayımlanmamış Yüksek Lisans Tezi. Bursa: Uludağ Üniversitesi, Eğitim Bilimleri Enstitüsü.

Dearden, R. F. (1981). Controversial issues in the curriculum. Journal of Curriculum Studies, 13(1), 37-44.

Deveci, A. (2009). Illköğretim yedinci sınıf öğrencilerinin maddenin yapısı konusunda sosyobilimsel argümantasyon, bilgi seviyeleri ve bilişsel düşünme becerilerini geliştirmek. Yayımlanmamış Yüksek Lisans Tezi. İstanbul: Marmara Üniversitesi, Eğitim Bilimleri Enstitüsü.

Domaç, G.G. (2011). Biyoloji eğitiminde toplumbilimsel konuların öğrenilmesinde argümantasyon tabanlı öğrenme sürecinin etkisi. Yayımlanmamış Yüksek Lisans Tezi. Ankara: Gazi Üniversitesi, Eğitim Bilimleri Enstitüsü.

Evans, R. W. (2010). The social studies wars: now and then. W. C. Parker (Ed.), in Social studies today: Research and practice (pp. 25-34). New York: Routledge.

Kruger, T. (2012). Teaching controversial issues in social studies: A phenomenological multi-case study. Yayımlanmamış Doktora Tezi, Northern Illinois University, Dekab Illinois.

Fındıkçı, i. (2004). Yaşadıkça Eğitim. İstanbul: Hayat Yayıncılık. 
Şefika TATAR | Oktay Cem ADIGÜZEL

Goloğlu, S. (2009). Fen eğitiminde sosyo-bilimsel aktivitelerle karar verme becerilerinin geliştirilmesi: dengeli beslenme. Yayımlanmamış Yüksek Lisans Tezi. İstanbul: Marmara Üniversitesi, Eğitim Bilimleri Enstitüsü.

Gözüm, A. i.C. (2015). Okul öncesi, sınıf ve fen bilgisi öğretmenlerinin fen bilimleri öz yeterliklerine göre sosyo-bilimsel tutum ve bilişsel yapılarının belirlenmesi (Kars ili örneği). Yayımlanmamış Doktora Tezi. Samsun: Ondokuz Mayıs Üniversitesi, Eğitim Bilimleri Enstitüsü.

Gülhan, F. (2012). Sosyo-bilimsel konularda bilimsel tartışmanın 8. sınıf öğrencilerinin fen okuryazarlığı, bilimsel tartışmaya eğilim, karar verme becerileri ve bilim-toplum sorunlarına duyarlııklarına etkisinin araştırılması. Yayımlanmamış Yüksek Lisans Tezi. İstanbul: Marmara Üniversitesi, Eğitim Bilimleri Enstitüsü.

Healey, R. L. (2012). The power of debate: reflections on the potential of debates for engaging students in critical thinking about controversial geographical topics. Journal of Geography in Higher Education, 36 (2), 239-257.

Hoge, J.D. (1988). Civic education in schools. (ERIC Clearinghouse for Social Studies/Social Science Education Bloomington IN. ED 301531). https://www.ericdigests.org/pre-9210/civic.htm (Erişim tarihi: 07.11.2016).

Karahan, E. (2015). Case studies of secondary school teachers designing socioscientific issuesbased instruction and their students' socioscientific reasoning. Yayımlanmamış Doktora Tezi. Minnesota: University of Minnesota.

Karakaya, F. (2011). Ortaöğretim öğrencilerinin hayvanların deneylerde kullanımı ile ilgili sahip oldukları etik değerlerin çeşitli değişkenler açısından incelenmesi. Yayımlanmamış Yüksek Lisans Tezi. Ankara: Gazi Üniversitesi, Eğitim Bilimleri Enstitüsü.

Karışan, D. (2014). Öğretmen adaylarının reflektif muhakeme ve argümantasyon yeteneklerinin sosyobilimsel konulara ve sorgulayıcı öğretime dayalı laboratuvar dersinde incelenmesi. Yayımlanmamış Yüksek Lisans Tezi. Ankara: Ortadoğu Teknik Üniversitesi, Sosyal Bilimler Enstitüsü.

Khishfe, R. (2012). Nature of science and decision-making. International Journal of Science Education, 34 (1), 67-100.

Koçyiğit, A. (2015). Fen bilimleri öğretmenlerinin genetiği değiştirilmiş organizmalar (gdo) ve ürünleri konusunda bilgi düzeyleri, öz yeterlik inançları, tutum ve risk algılarının belirlenmesi. Yayımlanmamış Yüksek Lisans Tezi. Samsun: Ondokuz Mayıs Üniversitesi, Eğitim Bilimleri Enstitüsü. 
Kutluca, A.Y. (2012). Fen ve teknoloji öğretmen adaylarının klonlamaya ilişkin bilimsel ve sosyobilimsel argümantasyon kalitelerinin alan bilgisi yönünden incelenmesi. Yayımlanmamış Yüksek Lisans Tezi. Bolu: Abant İzzet Baysal Üniversitesi, Eğitim Bilimleri Enstitüsü.

Levinson, R. (2006). Teachers' perceptions of the role of evidence in teaching controversial socio-scientific issues. The Curriculum Journal, 17(3), 247- 262.

Levinson, R. (2008). Promoting the role of the personal narrative in teaching controversial socio scientific issues. Science and Education, 17, 855-871.

Millî Eğitim Bakanlığı [MEB] (2005). Sosyal bilgiler dersi (4,5,6,7. sınıflar) öğretim programı.

MEB (2013). Fen bilimleri dersi (3,4,5,6,7,8. sınıflar) öğretim programı.

MEB (2017). Fen bilimleri dersi (3,4,5,6,7,8. sınıflar) öğretim programı.

MEB (2017). Sosyal bilgiler dersi (ilkokul ve ortaokul 4,5,6,7. sınıflar) öğretim programı.

National Council for Social Studies. [NCSS] (1992). A vision of powerful teaching and learning in social studies: building social understanding and civic efficacy. Social Education, 80 (3), 180-182.

NCSS (2016). Academic freedom and the social studies teacher. Social Education (May/June), 80 (3), 186.

Neal, L.S. (2013). From classroom to controversy: conflict in the teaching of religion. Teaching Theology and Religion, 16 (1), 66-75.

Öztürk, A. (2013). Sosyo-bilimsel konularla argümantasyon becerisi ve insan haklarına karşı tutum geliştirmeye yönelik bir eylem araştırması. Yayımlanmamış Doktora Tezi. Adana: Çukurova Üniversitesi, Sosyal Bilimler Enstitüsü.

Sadler, T. D. \& Zeidler, D.L. (2005). Patterns of informal reasoning in the context of socioscientific decision making. Journal of Research in Science Teaching, 42, 112138.

Sağlam, H. ì. (2016). Öğretmen adaylarının nükleer enerji kullanımına yönelik informal muhakemeleri üzerine karma yöntem araştırması. Yayımlanmamış Yüksek Lisans Tezi. Aksaray: Aksaray Üniversitesi, Sosyal Bilimler Enstitüsü.

Saylan, A. (2014). Relationships among pre-service science teachers' epistemological beliefs, knowledge level and trustworthiness on information sources: climate change, nuclear energy, and organ donation and transplantation. Yayımlanmamış Yüksek Lisans Tezi. Ankara: Orta Doğu Teknik Üniversitesi. 
Şefika TATAR | Oktay Cem ADIGÜZEL

Sevgi, Y. (2016). Gazete haberlerindeki sosyobilimsel konuların argümantasyon yöntemiyle tartışılmasının ortaokul 7.sınıf öğrencilerinin eleştirel düşünme, karar verme ve argümantasyon becerilerine etkisi. Yayımlanmamış Yüksek Lisans Tezi. İstanbul: Marmara Üniversitesi, Eğitim Bilimleri Enstitüsü.

Soysal, Y. (2012). Sosyobilimsel argümantasyon kalitesine alan bilgisi düzeyinin etkisi: genetiği değiştirilmiş organizmalar. Yayımlanmamış Yüksek Lisans Tezi. Bolu: Abant İzzet Baysal Üniversitesi, Eğitim Bilimleri Enstitüsü.

Sönmez, A. (2011). Fen ve teknoloji öğretmen adaylarının gdo'lu besinler hakkındaki bilgileri, risk algıları, tutumları ve böyle bir konunun öğretimine yönelik öz yeterlilikleri. Yayımlanmamış Yüksek Lisans Tezi. Kırşehir: Ahi Evran Üniversitesi, Fen Bilimleri Enstitüsü.

Sönmez, A. (2015). Fen bilimleri öğretmenlerinin epistemolojik inanç sistemleri ve sosyobilimsel konular hakkında yaptıkları öğretimler arasındaki ilişkilerin belirlenmesi. Yayımlanmamış Doktora Tezi. Bolu: Abant İzzet Baysal Üniversitesi, Eğitim Bilimleri Enstitüsü.

Sürmeli, H. (2008). Üniversite öğrencilerinin biyoteknoloji ve genetik mühendisliği çalışmaları ile ilgili tutum, bilgi ve biyoetik görüşlerinin değerlendirilmesi. Yayımlanmamış Yüksek Lisans Tezi. İstanbul: Marmara Üniversitesi, Eğitim Bilimleri Enstitüsü.

Şahintürk, G. Y. (2014). Sosyo-bilimsel tartışma destekli fen etkinliklerinin 8. sınıf öğrencilerinin yenilenebilir enerji kaynakları ile ilgili farkındalıkları ve içerik bilgisi gelişimine etkisinin incelenmesi. Yayımlanmamış Yüksek Lisans Tezi. İstanbul: Marmara Üniversitesi, Eğitim Bilimleri Enstitüsü.

Taşpınar, P. (2011). Sosyobilimsel tartışma destekli sağlık eğitimi etkinliklerinin ilköğretim 5. sınıf öğrencilerinde sağlık bilincinin ve içerik bilgisinin gelişimine etkisi. Yayımlanmamış Yüksek Lisans Tezi. İstanbul: Marmara Üniversitesi, Eğitim Bilimleri Enstitüsü.

Topaloğlu, M. Y. (2016). Sosyobilimsel konulara dayalı okul dışı ortamlarının öğrencilerin kavramsal anlamalarına ve karar verme becerilerine etkisi. Yayımlanmamış Yüksek Lisans Tezi. Sakarya: Sakarya Üniversitesi, Eğitim Bilimleri Enstitüsü.

Topçu, M. S. (2008). Preservice science teachers' informal reasoning regarding socioscientific issues and the factors influencıng their informal reasoning. Yayımlanmamış Doktora Tezi. Ankara: Ortadoğu Teknik Üniversitesi, Sosyal Bilimler Enstitüsü. 
Urhan, G. (2016). Argümantasyon tabanlı ögrenme ortamlarında öğrencilerin argüman kalitelerinin ve informal akıl yürütme becerilerinin incelenmesi. Yayımlanmamış Yüksek Lisans Tezi. Ankara: Gazi Üniversitesi, Eğitim Bilimleri Enstitüsü.

Wellington, J. (1986). Controversial issues in the curriculum. Oxford: Blackwell.

Yaman, H. H. (2011). Argümantasyon tabanlı biyoetik eğitiminde örnek bir uygulama: genetiği değiştirilmiş organizma ve genetik tarama testi. Yayımlanmamış Yüksek Lisans Tezi. Ankara: Gazi Üniversitesi, Eğitim Bilimleri Enstitüsü.

Yetişir, M. I ve Kaptan, F. (2008). Sts from a historical perspective and its reflection on the curricula in Turkey. International Journal of Environmental \& Science Education, 3(1), 3-8.

Yüce, Z. (2011). Fen bilgisi öğretmenliği öğrencilerinin biyoteknoloji konusundaki bilgileri ve biyoteknoloji uygulamalarına yönelik biyoetik yaklaşımları: tutum, görüş ve değer yargıları. Yayımlanmamış Yüksek Lisans Tezi. Ankara: Gazi Üniversitesi, Eğitim Bilimleri Enstitüsü. 